\title{
STRATEGIC MANAGEMENT OF HEALTHCARE INSTITUTION DEVELOPMENT OF THE NATIONAL MEDICAL SERVICES MARKET
}

\author{
Inesa Mikhno ${ }^{1}$, Viktor Koval ${ }^{2}$, Anton Ternavskyi ${ }^{3}$ \\ ${ }^{1}$ Private Higher Educational Institution "International European University", Kyiv, Ukraine \\ ${ }^{2}$ Odessa Institute of Trade and Economics of Kyiv National University of Trade and Economics, Odessa, Ukraine \\ ${ }^{3}$ Institute of Market Problems and Economic and Ecological Research NAS of Ukraine, Odessa, Ukraine \\ e-mail: ${ }^{1}$ victor-koval@ukr.net, ${ }^{2}$ inessa.mihno@gmail.com, ${ }^{3}$ antonternavskij13@gmail.com
}

Received: 01 July 2020; Accepted: 13 August 2020; Published: 01 September 2020

\begin{abstract}
The article reviews the current state of the market of medical services in Europe and comparatively results with the health care system in Ukraine. The main problems of reforming the health care system of Ukraine, which is characterized by the reduction of public health institutions, insufficient funding and an increase in the number of private clinics aimed at maximizing profits, are analyzed. On the one hand, this improves the quality of medical services, as private clinics, not having public funding, but financed by consumers purchase expensive equipment and make decisions in market conditions, which contributes to the introduction of new methods and innovative technologies, while on the other hand private medicine is inaccessible to the vast majority of the population of Ukraine due to the low economic status of citizens. The article considers the problem of remoteness of settlements from health care institutions and gives recommendations for further development and management of the health care system on the national market of medical services to reduce the risk of premature loss of population and improve the health of patients. The main reasons for the decline of the population of Ukraine are described and recommendations for the transition from public to public private medicine are provided. It was found that it is necessary to increase funding for public healthcare institutions and increase their total number to preserve the human potential of Ukraine. It was concluded that the strategic management of the development of the health care system should constantly monitor the effectiveness of implementation of changes, develop a flexible system of reform and control, which would take into account regional characteristics and mentality of the Ukrainian population. In order to increase the results of public medicine functioning and improve its availability and competitiveness, it is necessary to reorganize the system of control over the targeted use of monetary resources and develop a step-by-step strategy of Ukraine's development in all areas of the medical services market.
\end{abstract}

Key words: strategic management, healthcare institution, national market, medical services, human potential.

JEL classification: I15; J10; L10, O43

How to Cite:

Mikhno I., Koval V., Ternavskyi A. 2020. Strategic management of healthcare institution development of the national medical services market. Access journal, ACCESS Press, 1(2): 157-170, https://doi.org/10.46656/access.2020.1.2(7)

\section{INTRODUCTION}

Regulation of national health policy is an extremely important factor in the existence of the state and an indicator of the quality of life. Proper management decisions in the health care sector contribute to strengthening and preserving the health of the working population of the country, solving the problems of demography, improving the quality of labor resources, increasing productivity, which is especially important for the development of the country's economy, increasing Gross Domestic Product (GDP) (Malyarets et al, 2019; Matyushenko et al., 2020). 
In recent years, there has been an increase in morbidity in the working age of the population of Ukraine and an increase in immigration, which reduces the labor potential. The main world trends and directions of strategic management in health care are developed by the World Health Organization (WHO), however, each country has its own priorities and features that determine the general provisions and concepts that are considered by the state leadership. When developing a national program on safety and hygiene, goals and objectives should be formulated taking into account the stated priorities, developed means and methods of achieving them, as well as ways to assess the results achieved and general access of each citizen to information on changes and opportunities.

The quality of medical services determines the amount of expenses per capita and the quality of use of these funds. In Ukraine, health care costs are much lower than in European countries, which affects the quality of the health care system as a whole. The level of national spending on health care is a relative value calculated as a total amount of public and private spending on health care during a calendar year and is a reflection of the attitude of the state and society towards citizens' health (Andriyash, Malikina, Polyakova, 2019). The level of quality of health care services in Ukraine is much lower than in developed countries and the population health indicators in Ukraine have a negative trend. In Ukraine there is a lack of funding from the state for health care. This leads to an increase in the share of personal expenses for medical care. Taking into account the sociopolitical importance of health preservation of the population on the part of the state, the role and importance of the mechanisms of state management in the restructuring of health care systems is increasing (Shohet, 2006; Safonov\&Borshch, 2019).

\section{The purpose of the work}

Taking into account the increase in morbidity of the population of Ukraine and the prevalence of population decline over the birth rate, the aim of the article is to analyze the current situation and strategic management of the development of health care institutions on the national market of medical services, which would contribute to the improvement of the quality of life of the population and increase in the human potential of the country.

\section{Results}

The main reasons for the decline of the population in Ukraine in 2018, according to the State Statistics Committee and other sources of information were diseases of the circulatory system (387029), neoplasms (77551) and injuries, poisoning (30718) and some other consequences of external factors (Ukrainian Center for Social Data, 2019). Such a reason of population decline as the old age is only $10 \%$ in Ukraine from other reasons, which indicates the possibility of improving the health care system and its unsatisfactory condition.

Since the existence of independent Ukraine, the structure of health care expenses has changed. In the Soviet Union, there was only state medicine, which was based on a system of national and municipal health care institutions that were accessible to every citizen. 
The set of social needs and priority directions of development for each region were strictly regulated. Since 1991, private hospitals have appeared, the number of which is constantly growing in Ukraine, as well as the growth of private sector funding for health care (Fig. 1). All this contributes to the growth of responsibility of each person in relation to his or her health condition and reduces the influence of the state on the behavior of the actors. However, due to the low economic standard of living of the majority of Ukrainian citizens, private medicine is not available, so the existence of state free medicine is mandatory, its quality determines the labor potential of the country and sets the vector for future development.

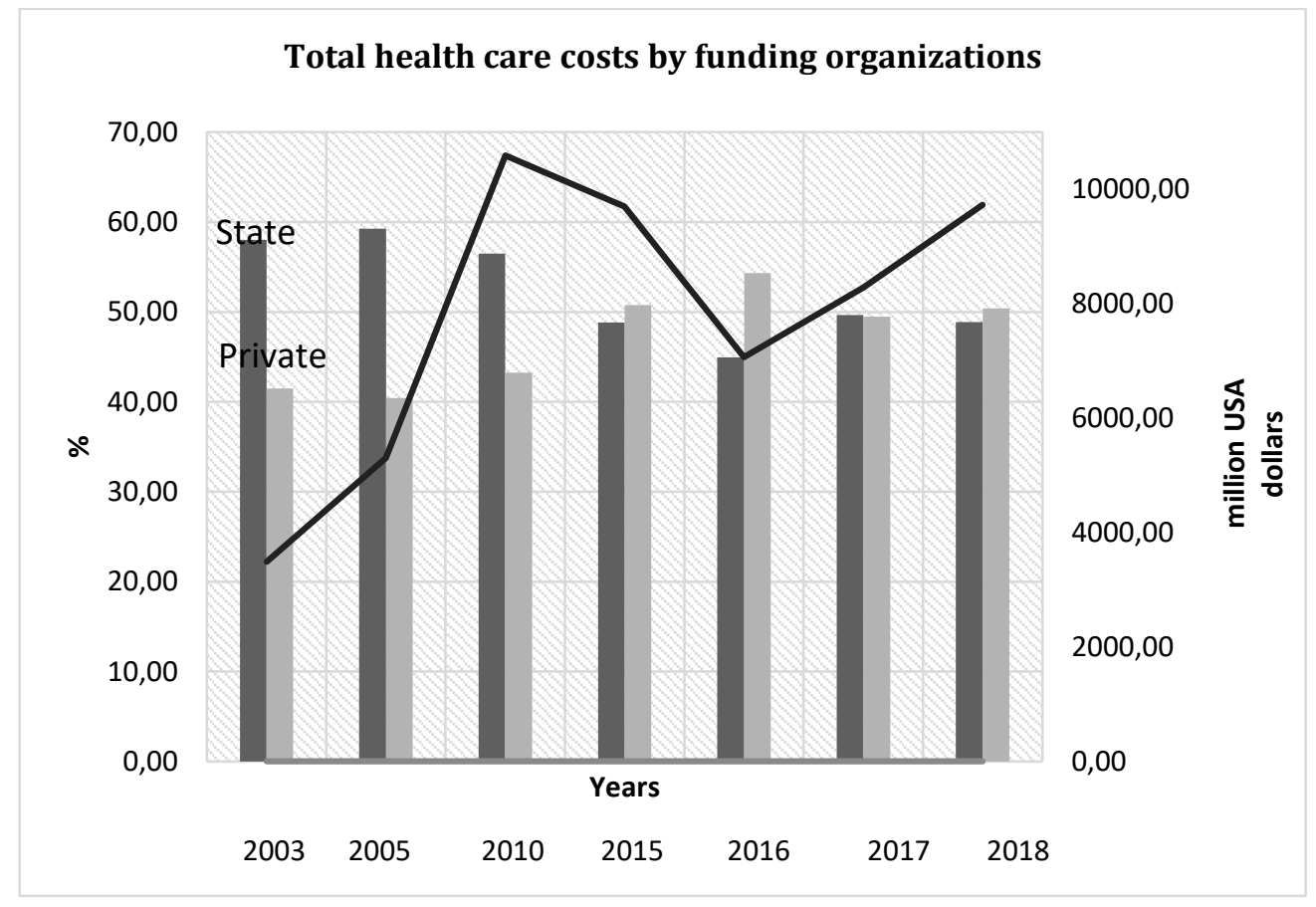

Fig. 1. Total health care costs by funding organizations in Ukraine

Source: Ukrainian Center for Social Data (2019), State statistics service of Ukraine (2020)

From Fig. 1 we can see that in the time interval of 15 years the percentage of government funding for health care decreases, while the percentage of funding by the private sector increases. Total health care expenditures in dollar equivalent are also slowly growing, however, we see their decline in 2016 due to the introduction of new medical reform, changes in development strategies and the leadership of the Ministry of Health, along with the economic crisis and instability in Ukraine. The general trend in the majority of countries of the world and Ukraine contributes to the increase in the percentage of private sector funding for health care and the development of private or insurance medicine. Due to the decrease in funding for state health care institutions, their number is also decreasing in comparison with the number in the Soviet Union. The location structure of medical and health care institutions is also changing due to the outflow of citizens from urban-type settlements and towns to large cities. 
As a result of urbanization, environmental changes and an increase in the morbidity rate are becoming a consequence, which increases the burden on hospitals in cities and reduces the flow of population to health care facilities in small communities (Koval, Mikhno, 2019; Sushchenko et al, 2019).

At the time of the planned economy, decisions on financing the health care system and regulating the number of health improvement measures and their activities were fully subordinated to the state authorities (Levashova, 2011; Ponomarenko\&Gontareva, 2017). With functioning of the market system, the private sector accounts for a growing share of funds for health care development, which is becoming more powerful every year. The existence of grants and programs to support health care institutions is not sufficient for their full functioning, constant updating with respect to scientific and technological progress and maintenance in the number corresponding to 1990. Further preservation of the state monopoly is impossible, but in order to preserve the nation's health, the state must develop a clear strategy for further actions that would improve the quality of life of the population and be publicly available. Currently, all types and regional features of private medicine are considered as a single system that exists to generate a profit when investing private funds in business development. Regulation of private medicine is carried out by the Ministry of Health of Ukraine (2020), however, for compliance with standards and quality of services corresponds to an entrepreneur in a competitive environment (Lazarova, Zhelyazkova, Vazov, 2015).

On the one hand, this brings the modern medical industry to a better level through private investment, and on the other hand, makes it inaccessible to many segments of the population. The best option for the development of private medicine is to create conditions in which the health care system of Ukraine can get the maximum investment and build a system of independent institutions for the provision of medical services on competitive terms with the functioning of the free market (Naama, 2001; Sushchenko, 2016). However, this strategy is the best option in large cities where there is a constant flow of capital and the standard of living of the population is significantly higher than in the periphery. As for small communities, the national concept should be free and accessible medicine throughout the country.

From Fig. 2 we can see a decrease in the number of hospital institutions in Ukraine at the whole time interval from 3.9 thousand units (1990) to 1.7 thousand units. (2017). Although the territories of the Autonomous Republic of Crimea and part of Donetsk and Luhansk oblasts have not been taken into account since 2014, the total number of medical institutions is still declining. This is most often due to the reorganization of hospitals, their closure in small communities and the reduction of their total number in Ukraine due to insufficient funding. Trends in the reduction of health care institutions may hinder the health of citizens and significantly reduce the quality of life of the population. A large number of diseases, especially those associated with poor blood circulation and injuries require immediate hospitalization of the patient, and long distances between hospitals and poor road conditions cause an increase in population decline or deterioration. The number of hospital beds also decreases over time. 


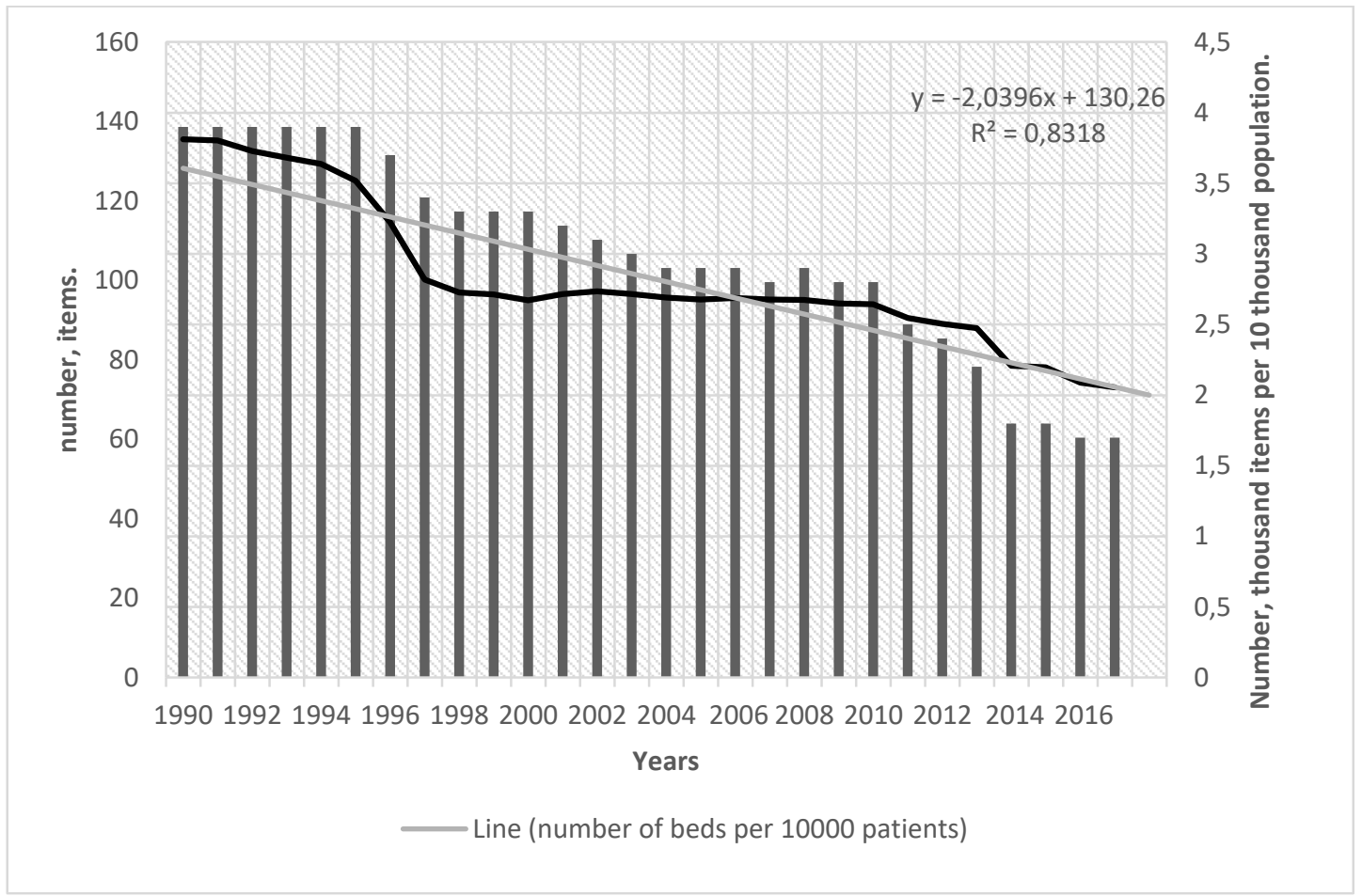

Fig. 2. Number of hospitals in Ukraine in the time interval

Source: Ukrainian Center for Social Data (2019), State statistics service of Ukraine (2020)

The main goal of creating a health care system is to improve the living conditions and healthcare of the population, promote a healthy lifestyle and increase the labor potential of the country, which will contribute to the reduction of possible health risks for citizens.

In the United States and a number of developed countries, there is insurance medicine, which depends on the accumulated deposits during the period of service. State insurance medicine does not cover all costs and is available in the areas specified in the contract. And although government spending on health care in developed countries is quite high compared to Ukraine, not all existing healthcare systems are more efficient. In particular, insurance medicine is a system that emerged during the period of the market system and has the influence of large pharmaceutical corporations and clinics, which can correct the actions of physicians and influence the market for medicines and services. An example would be the U.S. health care system, where it is difficult for the government to adjust prices for medicines and part of the population cannot afford quality treatment, while private medicine partially interacts with the government and has high prices for services compared to Ukraine. Not all employers buy the maximum insurance policy, what to say about the use of human resources and unwillingness of employers to take care of their employees, and the population is not able to buy enough drugs and medical services on their own (Nenkov, Sushchenko, Dyachenko, 2017). All this leads to increased morbidity and population decline. In addition to the high prices of health care products in the United States, there is a problem with the use of government programs. Many people are unable to formalize treatment or are unaware of its availability, while private medicine, with its strong advertising, generates a steady income to keep U.S. citizens healthy. The U.S. health care system cannot be successfully implemented in Ukraine 
because of the lower economic standard of living, the developed shadow sector, where most people work without official registration, so employers will not buy insurance policies (Vazov, 2019). Another significant obstacle will be the introduction of family doctors and reduced access to narrow specialists due to the untimely provision of medical services and the availability of queues to specialized doctors in public health care institutions (Hutsaliuk, 2020).

In most countries of the world with market economies, there are new organizational forms of medical institutions, especially medical centers - universal or focused on a particular type of pathology, with different forms of funding, mostly private. In Ukraine such centers are becoming more and more popular and have a powerful material and technical base in comparison with the majority of state medical institutions, but financing in such centers is higher in price and therefore not affordable for most citizens of Ukraine.

The basis of the nation's health is also an extensive system of medical and preventive health facilities, the number of which is also constantly declining with the construction of private sanatoriums and resorts, which are aimed at maximizing profits.

Preventive measures are aimed at reducing risk factors that may affect the health of citizens and have an extensive system of health facilities, which since 1991 have been actively privatized or discontinued, resulting in a reduction in their number. The number of publicly funded children's health care institutions also continues to decline.

The average number of doctors in Ukraine is 440 people. per 100 thousand citizens, while Sweden (540 people), Austria (513 people), Norway (466 people) (World Health Organization, 2018). However, the incidence rate in Ukraine is significantly higher than in other European countries, due to lower economic levels, environmental problems and others (Naama, 2011).

The decline of Ukraine's population is quite high in comparison with developed countries (Fig. 3) for the negative impact of external factors on public health, in particular, low living standards with high negative environmental and physical stress (Koval et al., 2019; Koval et al., 2020). The existence of large factories that have obsolete equipment, non-compliance with environmental standards and high levels of corruption make Ukraine a country with an increased risk to life, and the failure to reform the health care system and reduce its funding is the reason for the country's shrinking population and aging nation.

From Fig. 3, we can see that population decline caused by cardiovascular diseases is increasing in the time interval, and the trend line has a positive tilt angle, which indicates negative trends in health care. The increased risk to public health is also due to the reduced availability of health facilities and medicines in Ukraine. At the same time, new technologies are being introduced in the world and new methods of treatment for many diseases are appearing. Scientific progress and development of information technologies should significantly reduce population losses and increase life expectancy, which is observed in developed countries, while in Ukraine life expectancy is growing slowly and is about 72 years, while in Switzerland, Spain, Australia, Singapore, France it is about 83 years (World Health Organization, 2018). 


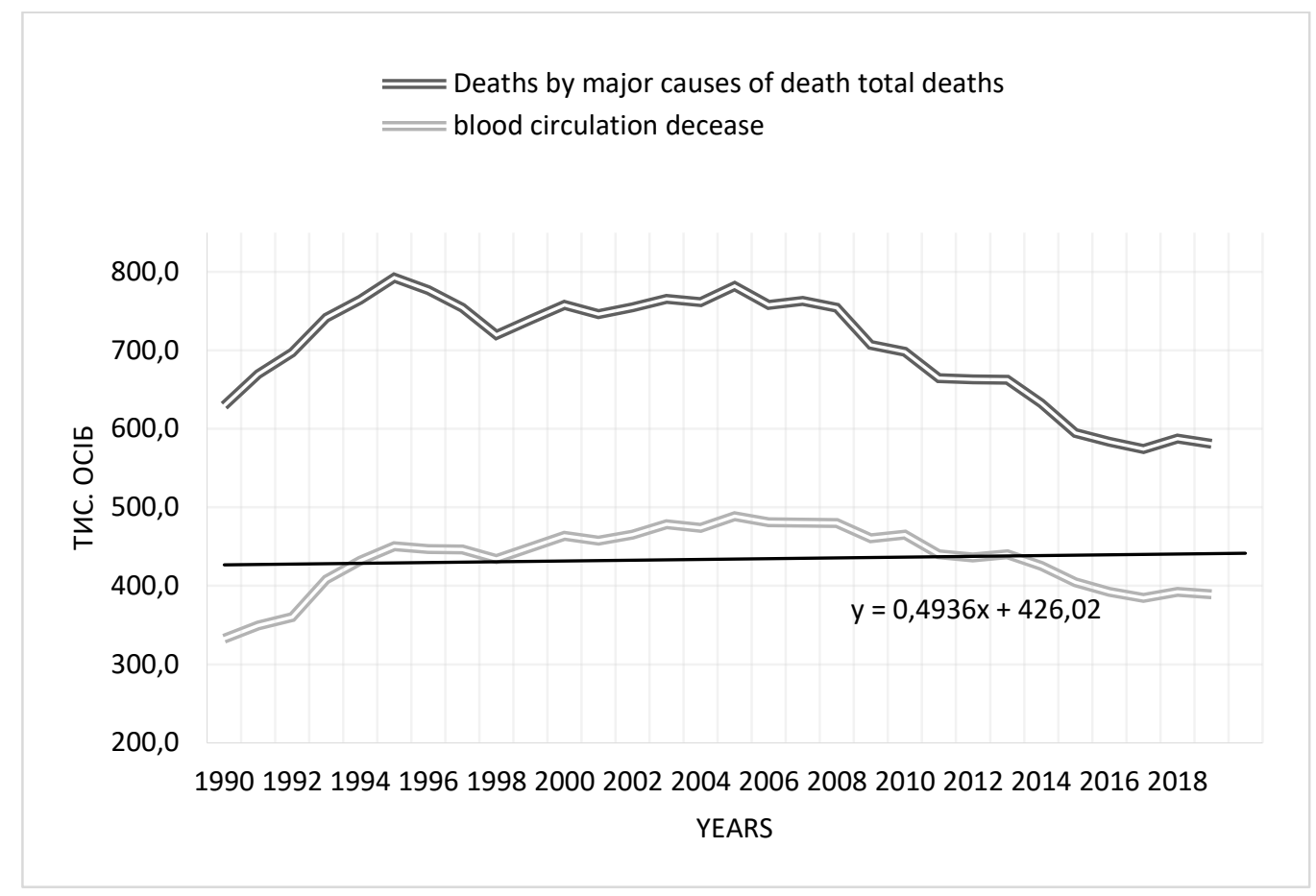

Fig. 3. Population decline in Ukraine in the time interval Source: Ukrainian Center for Social Data (2019), State statistics service of Ukraine (2020)

Numbeo (2020) has compiled a list of countries by level of health care, which varies from 0 to 100 . The higher the index, the better the quality of health care.

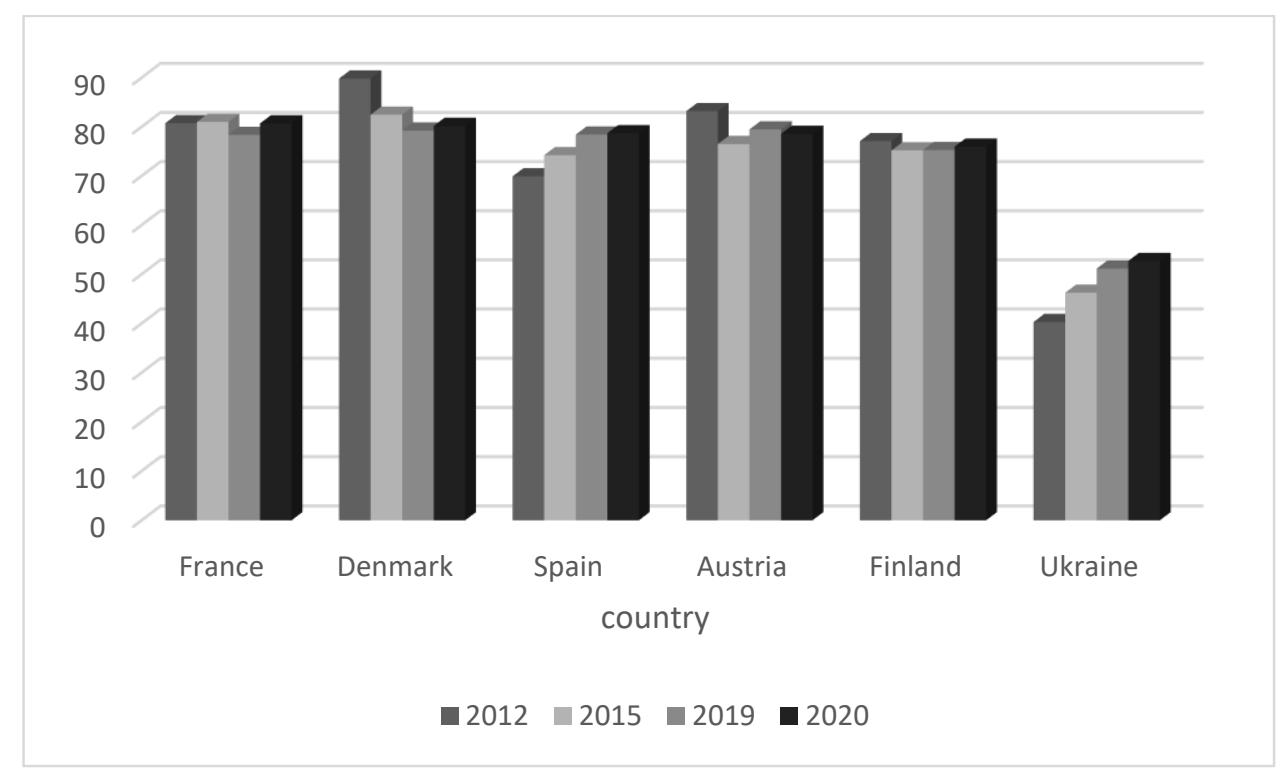

Fig. 4. Health Care Index by Country

Source: World Health Organization (2018), State statistics service of Ukraine (2020)

From Fig. 4, we can see that the indicator of quality of medical care in Ukraine is much lower than in developed European countries. In 2020, it was about 53, and in France it was about 81. In recent years, there 
has been an improvement in the quality of medical care in Ukraine, which is due to the development of private medicine and the introduction of new methods of treatment. If we consider public health institutions, the situation is worsening. One of the main problems in Ukraine is the closure of medical facilities in small communities and reorganization, which contributes to the closure of medical facilities with a small workload.

One of the reasons for premature population decline in Ukraine is the untimely assistance in the development of cardiovascular diseases (Fig. 3). In case of liquidation of medical institutions in settlements with low population density and poor road surface, which is typical for the most part of Ukraine, the risk for the population increases.

The reforms that are currently being implemented in Ukraine contribute to the reduction of the quality of health care and create additional risk factors in the presence of diseases and the need for urgent hospitalization.

The map of the Ministry of Health of Ukraine shows the number of medical institutions (Fig. 5).

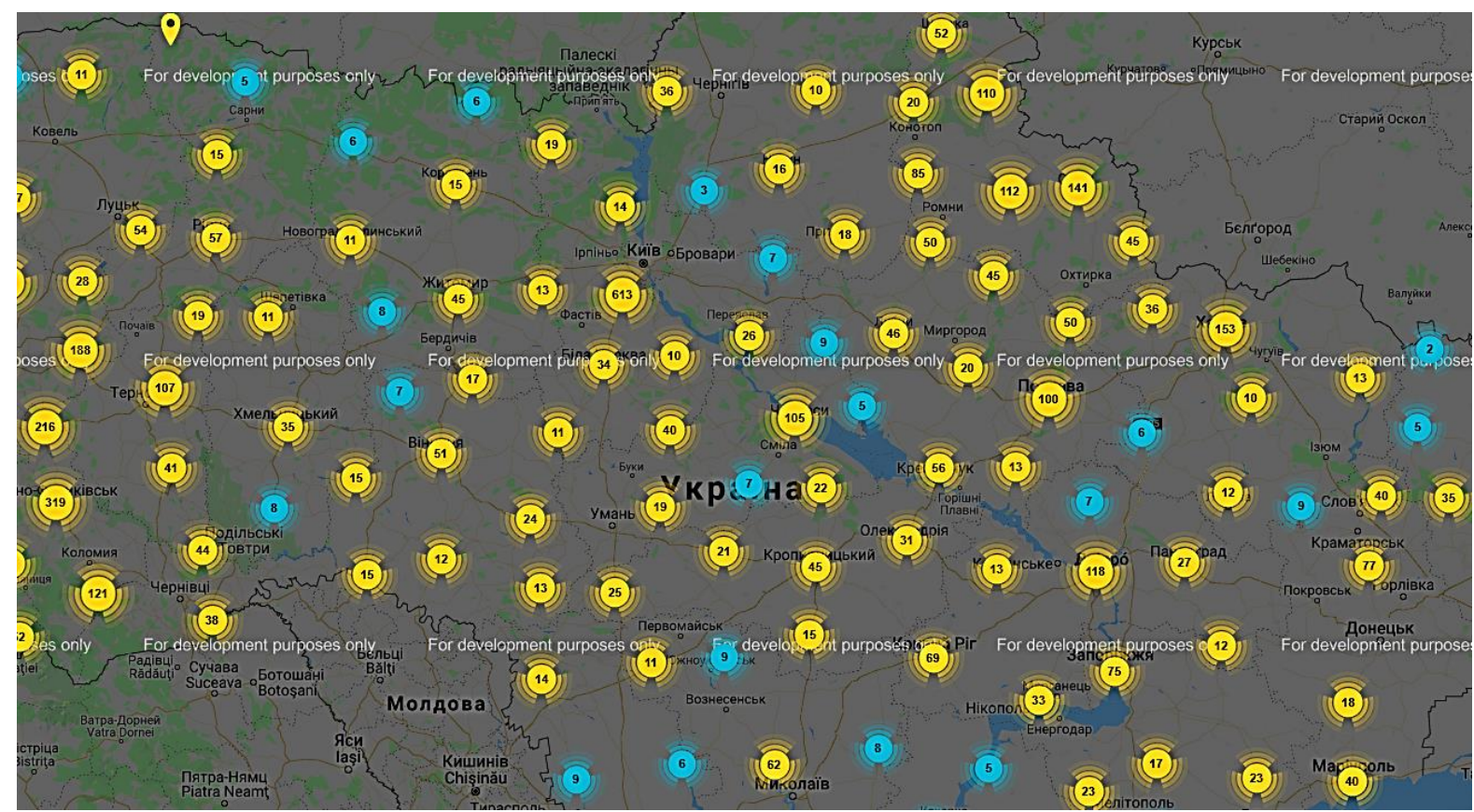

Fig. 5. Map of medical institutions of Ukraine

Source: Ministry of Health of Ukraine (2020)

From fig. 5, we see that in some settlements of the district significance there are less than 10 medical institutions and in many settlements there are no such institutions at all. Taking into account the terrain and quality of road surface, we can conclude that the health care system in Ukraine is in an unsatisfactory state. The situation is especially worsening in the mountainous areas of the Carpathians, where the distance between settlements is increasing due to the presence of serpentines, bridges and tunnels.

The time of access to medical care institutions in Ukraine shall not exceed the threshold values. Otherwise, health risks for citizens living in remote areas are growing, and the living standards of the population of Ukraine are decreasing, which affects the effective macroeconomic indicators. 
Thresholds, in our opinion, should be the distances (for multidisciplinary medical institutions that can provide high-tech care), which can be reached by car in no more than 60 minutes in compliance with all established traffic rules. The second threshold value should be the distance to the nearest primary health care station. This distance should not be more than the distance that a person can walk 60 minutes, that is, no more than $7 \mathrm{~km}$.

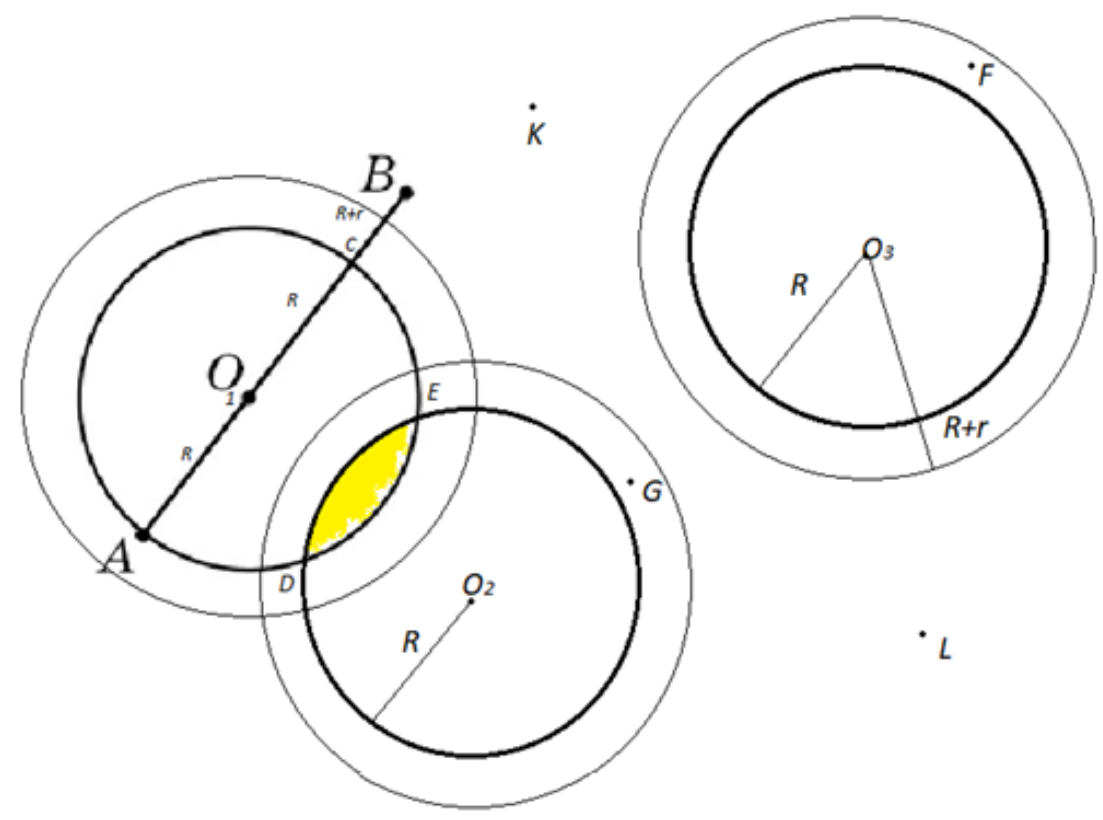

Fig. 6. Location of primary health care centers and distance from them to settlements Source: prepared by the authors

Figure 6 shows the scheme of location of 3 primary care institutions - $\mathrm{O}_{1}, \mathrm{O}_{2}, \mathrm{O}_{3}$ and location of settlements relatively to them. All settlements that are within a radius of $7 \mathrm{~km}$ (distance R, OC) are favorable for living. $\mathrm{r}$ distance, which increases the risks caused by the remoteness of primary health care centers of $3.5 \mathrm{~km}$. Localities that are in the second circle and have a distance greater than $R$ and less or the one equal to $R+r(G, F)$ is an area of increased risk for living. The settlements located behind the circles and the distance from which to the nearest primary health care institution is more than $10 \mathrm{~km}$ are dangerous for living (Table 1).

These are points B, K, L. Moreover, every $1 \mathrm{~km}$ the risk of premature population decline due to untimely medical care increases by $0.6 \%$ for critically ill patients (calculated as the average according to the State Statistics Committee of Ukraine, 2020).The area between points D and E, painted yellow, is a territory that has a choice when it comes to providing primary health care, so favorable for living.

For hospitals, where there is an outpatient department, hardware and multidisciplinary specialists, the radius of accessibility R should be $60 \mathrm{~km}$, and the distance $\mathrm{R}+\mathrm{r}$ should be $90 \mathrm{~km}$. In this case, if the road surface is in poor condition, you should take into account the travel time. The maximum time for which the car should drive from the settlement to the hospital should be 1 hour. Otherwise, this area becomes a high-risk settlement.

Table 1. Risk of patients' health deterioration due to distance from health care facilities 


\begin{tabular}{|c|c|c|c|c|}
\hline $\begin{array}{l}\text { Type of medical } \\
\text { institution }\end{array}$ & $\begin{array}{l}\text { Distance to the } \\
\text { settlement } R+r\end{array}$ & $\begin{array}{l}\text { Excessive } \\
\text { distance } \\
\text { indicator } r\end{array}$ & Travel time & Degree of risk \\
\hline Primary care point & $\mathrm{R}+\mathrm{r}<=7$ & 0 & Up to 1 hour on foot & $\begin{array}{lll}\text { Low. Up } & \text { to } & 10 \% . \\
\text { Dependent } & \text { on } & \text { other } \\
\text { factors. } & & \\
\end{array}$ \\
\hline Primary care point & $7<\mathrm{R}+\mathrm{r}<=10$ & $<=3$ & Up to 2 hours on foot & Moderate. About $12 \%$. \\
\hline Primary care point & $R+r>10$ & $>3$ & More than 2 hours on foot & $\begin{array}{l}\text { It grows every } 1 \mathrm{~km} \text { by } \\
0.6 \% \text { when the patient } \\
\text { is in serious condition. }\end{array}$ \\
\hline Polyclinic & $R+r<=60$ & 0 & $\begin{array}{l}\text { Up to } 1 \text { hour by car, taking } \\
\text { into account all traffic rules }\end{array}$ & $\begin{array}{lll}\begin{array}{l}\text { Low. Up } \\
\text { Dependent }\end{array} \text { on } & 10 \% \text { other } \\
\text { factors. } & & \\
\text { fan }\end{array}$ \\
\hline Polyclinic & $60<\mathrm{R}+\mathrm{r}<=90$ & $<=30$ & $\begin{array}{l}\text { Up to } 1.5 \text { hours by car, taking } \\
\text { into account all traffic rules }\end{array}$ & Moderate. About $19 \%$. \\
\hline Polyclinic & $R+r>90$ & $>30$ & $\begin{array}{l}\text { More than } 1.5 \text { hours by car, } \\
\text { taking into account all traffic } \\
\text { rules }\end{array}$ & $\begin{array}{l}\text { It grows every km by } \\
0.9 \% \text { if the patient's } \\
\text { condition is severe. Has } \\
\text { a threshold value. }\end{array}$ \\
\hline
\end{tabular}

Source: prepared by the authors

From Table 1 we can see that the probability of complications due to the remoteness of medical care centers increases with the distance to the hospital. Most primary care facilities in Ukraine do not have the necessary equipment and can not provide assistance in full, so patients are transported to hospitals of district importance. With a bad roadway, part of which in Ukraine is about $70 \%$ more time to transport a patient, you need to take into account when calculating the risk arising from the remoteness of the settlement from medical care facilities.

Three key areas of management should be considered as the basis for the development of further health strategies: development of a network of health care and treatment facilities, creation of a material and technical base that would be modern, effective and accessible to the entire population, training and qualified personnel, including continuous professional training of employees and access to innovative methods and equipment. To improve health outcomes, the Ministry of Health and the World Health Organization have developed a system of competencies necessary for each worker to master. To improve the quality of medicine, the state should constantly conduct advanced training courses, facilitate the attendance of conferences by medical workers and the exchange of information between foreign and Ukrainian doctors. To form strategies in personnel management, it is better to use the methodology for identifying key competencies and their mastery and further development.

In the sphere of health care, the state should have a dominant role, control the availability of services, the quality of their provision and pricing policy in the sphere of health care, set a price ceiling for the provision of medical services in the sale of goods. Another important aspect should be the process of involving private nonprofit structures, private commercial organizations, other organizational and legal forms in the management of health care in order to improve its functioning. 
The development of private medicine should not be an obstacle to the functioning of public medicine and not be the only option for citizens that will make access to medical goods and services inaccessible to the majority of the population, so the basis of strategic management of health care should be free, accessible and high quality of service provision, which will help improve the country's labor potential. This will help reduce social payments for the population who loses their ability to work due to a decrease in their number, improve efficiency, which will increase Ukraine's GDP.

To improve adaptability in the strategic management of health care institutions will help to introduce the newest technologies along with increased motivation for medical personnel, which is primarily possible with the improvement of medical financing (Baklanova, Petrova, Koval, 2020; Petrova et al., 2020). In forming strategies for each region, such measures should be conducted (Buchbinder, Shanks, Kite, 2019):

1. Formation of an effective network of medical and health care institutions while minimizing the risk associated with the remoteness of communities from the places of medical care, which are available on the map with the specified characteristics and distance from the location of each citizen;

2. Formation of an innovative development strategy, taking into account the best practices of foreign clinics and specialists using the latest methods;

3. Structural transformation that will improve the quality of services provided;

4. Creation of systems of development, testing and implementation centers for knowledge-intensive projects financed both from the state budget and from private investments;

5. Compliance of competences specified in the Ministry of Health with the competences that employees of the health care sector have, creation of conditions for continuous improvement of service quality;

6. Organization of corporate relations and common information space with other medical institutions;

7. Formation of information-analytical strategic centers that provide training and decision-making of strategic decisions, search for innovative solutions and their dissemination among medical professionals, rapid response to situations that have developed;

8. Use of public medical education as a tool to improve the culture, responsible attitude towards their own health (taking into account regional specifics);

9. Formation of a medical system that is publicly available and free and has an upper limit on the basic medicines that population needs.

Reserves for increasing the life expectancy and improving the quality of life of the population lie in the area of their social and economic development, where the basis should be the maintenance of a healthy lifestyle, improving the living standards of disadvantaged segments of the population, employment programs and decent social security, prevention of aggressive behavior, combating extremist manifestations, increasing the level of education and improving financing of health care institutions simultaneously with the control over the use of funds and reducing the shadows effects on the activities of economic entities (Tumalavičius et al., 2017). 


\section{CONCLUSIONS}

The health care system of Ukraine is under development and is in the process of transformation, which has led to disparities and reduced quality of medical services. To improve the functioning of the health care system, work should be done to increase the number of medical institutions and restore the system of public access. The basis for development should be measures to increase the country's labor potential and quality of life, restore human resources and reduce the aging of the nation, which has been observed over the past decades.

In health care institutions, every citizen should receive assistance upon request no later than 8 hours, if his condition is not serious, so the number of public funding institutions should be increased to avoid queues and complications of diseases.

Innovative development of the medical sphere, high technology should be supported and financed by the state, and the latest devices and drugs should be publicly available throughout the country in public medical institutions.

To improve the human resources potential of medical institutions, it is necessary to organize wellcoordinated work of medical teams, access to information resources, continuous professional development and compliance of these professional competencies with the skills and interests of employees, to introduce mandatory foreign internships in leading medical institutions of the country.

In Ukraine, where there is political and economic instability, a flexible public health policy and adaptation of existing programs to regional specifics should be implemented, and the effectiveness of activities and changes should be constantly monitored.

In Ukraine it is necessary to balance state obligations to the population and the possibilities of their fulfillment, which would contribute to the improvement of the quality of life of the population and innovative development in the market conditions, where both public and private healthcare institutions would function successfully.

\section{Conflict of interests}

The authors declare no conflict of interest.

\section{References}

Andriyash, V., Malikina, O., \& Polyakova, E. (2019). International experience of financing reforms in health. Public Administration and Regional Development, 5, 474-492. DOI: https://doi.org/10.34132/pard2019.05.01.

Baklanova, O., Petrova, M., Koval V. (2020). Institutional Transmission in Economic Development. Ikonomicheski Izsledvania, 29(1), 68-91.

Buchbinder, S. B., Shanks, N. H., \& Kite, B. J. (2019). Introduction to health care management. Jones \& Bartlett Learning.

Ginter, P. M., Duncan, W. J., \& Swayne, L. E. (2018). The strategic management of health care organizations. John Wiley \& Sons..

Hutsaliuk O., Storozhuk O., Zhovnirchyk Ya., Zaiarniuk O., Kartsyhin D. (2020). Public administration and legal regulation effectiveness in the field of health care in the context of sustainable development. Revista Genero \& Direito, 9.2, 599-613. 
Koval, V., Mikhno I. (2019). Ecological sustainability preservation of national economy by waste management methods. Economics. Ecology. Socium, 3(2), 30-40.

Koval, V., Petrashevska, A., Popova, O., Mikhno, I., \& Gaska, K. (2019). Methodology of ecodiagnostics on the example of rural areas. Architecture Civil Engineering Environment, 12(1), 139-144. https://doi.org/10.21307/ACEE-2019$\underline{013}$

Koval, V., Mikhno, I., Trokhymets, O., Kustrich, L., Vdovenko, N. (2020). Modeling the interaction between environment and the economy considering the impact on ecosystem. E3S Web Conferences, 166, 13002. https://doi.org/10.1051/e3sconf/202016613002

Lazarova, T., Zhelyazkova, V., Vazov, R. (2015). Innovation leadership as a key concept in entrepreneurship. Proceedings of International Conference for Entrepreneurship, Innovation and Regional Development ICEIRD 2015, University of Sheffield, pp.275-287

Levashova, L. (2011). Marketing wewnętrzny w kontekście motywowania pracowników, w: Świerszcz K. i Nowacki W., Kształtowanie lojalności klientów w teorii $i$ w praktyce. Warszawa: Wydawnictwo Warszawska Wyższa Szkoła Ekonomiczna.

Levashova, L. (2011). Rozwój kariery zawodowej pracowników w aspekcie innowacji, w: Innowacje przedsiębiorstw a satysfakcja klientów w teorii i w praktyce, pod redakcją naukowa Świerszcz K. i Śliwa J. Warszawa: Wydawnictwo Społeczna Wyższa Szkoła Przedsiębiorczosci i Zarządzania w Łodzi.

Malyarets, L.; Dorokhov, O.; Koybichuk, V.; Dorokhova, L. (2019). Obtaining a Generalized Index of Bank Competitiveness Using a Fuzzy Approach. Journal of Central Banking Theory and Practice, 8(1), $163-182$. https://doi.org/10.2478/jcbtp-2019-0008

Matyushenko, I., Hlibko, S., Petrova, M. M., Pasmor, M. S., \& Loktionova, M. (2020). Assessment of the development of foreign trade in high-tech production of Ukraine under the association with the EU. Business, Management and Education, 18(1), 157-182. https://doi.org/10.3846/bme.2020.11578

Ministry of Health of Ukraine (2020). Map of medical institutions. Retrieved from https://moz.gov.ua/karta-medzakladivmed

Naama, K. (2001). International Movement of Foreign Direct Investments. Economic Thought journal, Bulgarian Academy of Sciences - Economic Research Institute, 5: 81-92. https://www.ceeol.com/search/articledetail id $=221618$

Naama, K. (2011). Problems and Solutions for Establishing the Private Sector in Developing Countries. Economic Archive. D. A.Tsenov Academy of Economics- Svishtov. ISSN: 0323-9004, eISSN: 2367-9301, 1: 28-41 https://www.ceeol.com/search/article-detail?id=168228

Nenkov, N., Sushchenko, O., Dyachenko Y. (2017) Role of chief information officer within the system of human resource development in the service organizations (tourism) // Economic Annals-XXI. - Issue 5-6. - Vol. 165. - P. 97-103.

Numbeo (2020). Cost of Living Index. Retrieved from https://www.numbeo.com

Petrova, M., Koval, V., Tepavicharova, M., Zerkal, A., Radchenko, A., \& Bondarchuk, N. (2020). The interaction between the human resources motivation and the commitment to the organization. Journal of Security and Sustainability Issues, 9(3), 897-907. https://doi.org/10.9770/jssi.2020.9.3(15)

Ponomarenko, V., Gontareva, I. (2017). The system of causal connections between entrepreneurial activity and economic development. Economic Annals - XXI, 165(5-6), 4-7. https://doi.org/10.21003/ea.V165-01

Safonov, Y. M., \& Borshch, V. I. (2019). Strategic model of managing healthcare facilities. Global Academics, 3(4), 1521.

Shohet, I. M. (2006). Key performance indicators for strategic healthcare facilities maintenance. Journal of Construction Engineering and Management, 132(4), 345-352.

State statistics service of Ukraine (2020). Retrieved from http://od.ukrstat.gov.ua

Sushchenko, O. (2016). Creation of innovation clusters as a line of enterprise competitiveness improvement in the field of foreign economic activity, Actual Problems of Economics, 177(3), 191-198

Sushchenko, O., Trunina, I., Klok, O., Loseva, O. (2019). Management technologies of ensuring environmental protection as the territory development strategic priority. SHS Web of Conferences 61, 01026, Volume 61, 2019. Innovative Economic Symposium 2018 - Milestones and Trends of World Economy (IES2018). https://doi.org/10.1051/shsconf/20196101026 
Tumalavičius, V., Veikša, I., Načisčionis, J., Zahars, V., \& Draskovic, V. (2017). Issues of the state and society security (part i): ensuring public security in the fight against crime. Journal of Security and Sustainability Issues, 6(3), 401418. http://doi.org/10.9770/jssi.2017.6.3(7)

Ukrainian Center for Social Data (2019). Retrieved from https://socialdata.org.ua/prosto_cyfry.

Vazov R. (2019). Inovative Approaches to Insurance Company Cash Flow Management (contemporary theoretical aspects). Sofia: VUZF Publishing House "St. Grigorii Bogoslov", ISBN: 978-954-8590-54-9, 136 p.

World Health Organization (2018). Life expectancy and Healthy life expectancy Data by country. Retrieved from https://apps.who.int/gho/data/node.main.688?lang=en

\section{About the authors:}

Inesa MIKHNO, PhD in Economics, Private Higher Educational Institution "International European University", Kyiv, Ukraine. Research interests: economics of industry, information technology and marketing innovation, production efficiency, environmental management

ORCID ID: https://orcid.org/0000-0003-3661-1965

Viktor KOVAL, Dr. Sc. (Economics), Professor, Odessa Institute of Trade and Economics of Kyiv National University of Trade and Economics. Research interests: economics of industry, production efficiency, environmental management, tourism.

ORCID ID: $\underline{\text { https://orcid.org/0000-0003-2562-4373 }}$

Anton TERNAVSKYI, Senior Lecturer, Dentistry Department N3 of Donetsk National Medical University, PhD Student of Institute of Market Problems and Economic and Ecological Research NAS of Ukraine, Odessa, Ukraine. Research interests: economics oxtf industry, production efficiency, environmental management, strategic management, healthcare institution.

ORCID ID: $\underline{\text { https://orcid.org/0000-0003-4866-8133 }}$ 